Vol. 12, No. 2, Juli 2021

\title{
INTERVENSI PEMERINTAH TERHADAP HARGA PASAR MENURUT IBNU KHALDUN PERSPEKTIF HUKUM ISLAM
}

\author{
Muh. Abdul Qudus \\ Universitas Hamzanwadi Lombok Timur \\ Email: dousnq@yahoo.com
}

\begin{abstract}
Abstrak
Tujuan dalam penelitian ini untuk mengetahui bagaimana bentuk intervensi pemerintah dalam penentuan harga pasar menurut Ibnu Khaldun dan ahli ekonomi Islam serta untuk mengetahui dampak intervensi pemerintah terhadap penentuan harga pasar di dalam ekonomi menurut syari'at Islam. Metode yang digunakan pada penelitian skripsi ini adalah: Metode penelitian pustaka (library research). Sedangkan teknis analisis data menggunakan analisis sederhana dengan mengumpulkan data primer dan data sekunder melalui tahapan-tahapan akumulasi, eliminasi, seleksi, integrasei, konklusi. Hasil penelitin ini menujukkan bahwa Penentuan harga pasar oleh pemerintah adalah salah satu dari kebijakan intervensinya guna untuk menjaga keseimbangan harga pasar adapun menurut para ahli dan ekonom baik muslim dan konvensional bahwa intervensi pemerintah diperlukan guna untuk menjaga keseimbangan harga pasar namun mereka juga ada yang berbeda pendapatnya mengenai boleh tidaknya pemerintah mengintervensi harga pasar.
\end{abstract}

\section{Kata kunci: Pasar, Ibnu Khaldun, Hukum Islam.}

\begin{abstract}
The purpose of this study is to find out how the form of government intervention in determining market prices according to Ibn Khaldun and Islamic economists and to determine the impact of government intervention on market price determination in the economy according to Islamic law. The methods used in this thesis research are: Library research method. Meanwhile, technical data analysis uses simple analysis by collecting primary data and secondary data through the stages of accumulation, elimination, selection, integration, and conclusion. The results of this study show that the determination of market prices by the government is one of its intervention policies in order to maintain the balance of market prices, according to experts and economists, both Muslim and conventional, that government intervention is needed to maintain the balance of market prices, but they also have different opinions regarding whether or not the government intervenes in market prices.
\end{abstract}

The keywords: Market, Ibn Khaldun, Islamic Law. 


\section{Vol. 12, No. 2, Juli 2021}

\section{PENDAHULUAN}

Kewajiban merealisasikan falah, pada dasarnya merupakan tugas seluruh economic agents, termasuk pemerintah dan masyarakat. Terdapat banyak aktivitas ekonomi yang tidak dapat diselenggarakan dengan baik oleh pasar, sehingga mengharuskan adanya peran aktif dari pemerintah maupun masyarakat. Di samping pemerintah, masyarakat harus perperan langsung. Terdapat fenomena market failure, government failure, dan citizen failure, yaitu kegagalan sektor-sektor ini dapat mencapai solusi optimum bagi permasalahan ekonomi. Oleh karena itu, tidak mungkin untuk merealisasikan falahhanya dengan bertumpu pada salah satu sektor. Pasar, pemerintah, dan masyarakat harus bergerak dan bekerja sama (ta'awun) dan menyelenggarakan aktivitas ekonomi untuk mencapai kesejahteraan umat.

Pemerintah dan masyarakat pada dasarnya adalah dua institusi yang memiliki fungsi dasar sama, yaitu untuk merealisasikan segala kewajiban kolektif atau kewajiban publik dalam mewujudkan falah. Dalam beberapa aspek, bentuk peran keduanya, pada hakikatnya dapat saling mengantikan dan saling melengkapi satu sama lainnya sesuai dengan situasi dan kondisi. Peran masyarakat akan menjadi semakin penting manakala pemerintah tidak dapat menjalankan tugas fard al-kifayah ini dengan baik (F3EI, 2012: 445-446). manakala pemerintah tidak dapat menjalankan tugas fard al-kifayah ini dengan baik. (F3EI, 2012: 445-446).

Pasar dalam ekonomi Islam menganut sistem bebas terkendali. Artinya, pemerintah boleh turun tangan jika keadaan memerlukan demi menjalin kepentinan masyarakat menjaga pasar agar berjalan sesuai dengan prinsip ekonomi Islam yang tidak memandang kepentingan individu diatas kepentingan bersama. (Azizah, Mabbarok. 2012)

Dalam konsep Islam, keberadaan pasar yang terbuka (bebas) memberikan kebebasan bagi masyarakat untuk ambil bagian dalam menentukan harga, sehingga harga ditentukan oleh kemampuan rill masyarakat dalam mengoptimalisasikan faktor produk yang ada didalamnya. Menutut ajaran Islam, wujud suatu pasar merupakan refleksi dari kemampuan masyarakat dalam memenuhi kebutuhan-kebutuhannya. Islam mengtur bagaimana keberadan suatu pasar tidak merugikan satu pihak dengan pihak lain. Oleh karena itu, keterlibatan produsen, konsumen, dan pemerintah di pasar di perlukan guna menyamakan persepsinya tentang keberadan suatu harga. Berkenaan 


\section{Vol. 12, No. 2, Juli 2021}

dengan intervensi pemerintah dalam penetapan harga, Islam membolehkannya selama menyangkut pemeliharaan maslahat untuk semua pihak. Islam menghargai hak penjual dan pembeli untuk menetapkan harga sekaligus melindungi keduanya. pemeliharaan maslahat untuk semua pihak. Islam menghargai hak penjual dan pembeli untuk menetapkan harga sekaligus melindungi keduanya. Islam membolehkannya, bahkan mewajibkan pemerintah melakukan intervensi harga, bila kenaikan harga menyebabkan adanya distori terhadap permintaan dan penawaran.

Pengaturan harga diperlukan bila kondisi pasar tidak menjamin adanya keuntungan disalah satu pihak. Pemerintah harus mengatur harga, misalnya bila kenaikan harga barang diatas kemampuan masyarakat, maka pemerintah melakukan pengaturan dengan operasi pasar. Sedangkan apabila harga terlalu turun sehingga merugikan produsen, pemerintah meningkatkan pembelian atas produk produsentersebut atas pasar. Peran pemerintah tersebut berlaku disaat ada masalah-masalah yang ekstrim sehingga pemerintah perlu memantau kondisi pasarsetiap saat guna melihat kemungkinan diperlukannya pengaturan harga. (Dakhoir Ahmad, 2017).

Pasar telah mendapatkan perhatian memadai dari para ulama klasik yaitu Ibnu Khaldun. Pemikiran-pemikiran Ibnu Khaldun tentang pasar tidak saja mampu memberikan analisis yang tajam tentang apa yang terjadi pada masa itu tetapi tergolong 'futuristik'. Ibnu Khaldun barangkali merupakan ekonomi muslim yang terbesar, karena demikian cemerlang dan luas bahasannya tentang ekonomi. Ia menulis banyak buku, antara lain; Muqadimah, Syarh Al-Burdah, sejumlah ringkasan atas buku-buku karya Ibn Rusyh, sebuah, sebuah catatan atas buku matiq, ringkasan(mukhtasar) kitab AlMahsul karya Fakhr Al-Din Al-Razi (ushul fiqh), sebuah buku sejarahyang terkenal, $A l$ Ibar wa Diwan Al-Mubtada' wa Al-Khabar fi Tarikh al-Arab wa al-'Ajam wa Al-Barbar. Dalam bukunya Muqadimah Ibnu Khaldun memberikan bahasan yang luas terhadap teori nilai, pembagian kerja dan perdagangan internasional, hukum permintaan dan penawaran, konsumsi, produksi, uang, siklus perdagangan, keuangan publik, dan beberapa bahasan, makroekonomi lainnya.

Secara umum Ibnu Khaldun sangat menekankan pentingnya suatu sistem pasar yang bebas, Ia menentang intervensi negara terhadap masalah ekonomi.dan percaya akan efesiensi sistem pasar yang bebas. Ia juga telah membahas tahap-tahap pertumbuhan dan 


\section{Vol. 12, No. 2, Juli 2021}

penurunan perekonomian dimana dapat saja berbeda antarasatu negara dengan negara lainnya.

Pengaruh dasar-dasar ekonomi yang ditulis oleh Ibnu Khaldun mempengaruhi jalannya pendirian dan paham-paham ekonomi internasional. Karangan ekonomi dari Ibnu Khaldun itu menjadi lampu di tengah-tengah kegelapan atau bintang di dalam cakrawala, yang telah memberi pedoman bagi teoriteori ekonomi Eropa khususnya dan teoriteori Ekonomi Internasional pada umumnya. Dan secara khusus Ibnu Khaldun juga membicarakan masalah harga pasar yang dikaitkan dengan intervensi pemerintah. (Khaldun, 2001)

\section{METODE PENELITIAN}

Dalam penelitian ini menggunakan penelitian pustaka (liberary research). Penelitian ini bertujuan untuk mengumpulkan data dan informasi dengan bantuan bermacam-macam material yang terdapat diruangan perpustakan offline maupun online, seperti: Al-Qur'an, kitabkitab, terjemahan, buku-buku, majalah, dokumen, catatan, jurnal, artikel, web (internet), dan bahan-bahan pusaka lainnya yang releven (Suharsimi, 2003:135).

Teknik dalam penyusunan skripsi ini adalah studi kepustakaan yaitu dengan menelusuri berbagai lireratur yang berkaitan dengan pembahasan. Teknik pengumpulan data, merupakan cara-cara teknis yang dilakukan oleh seorang peneliti dalam mengumpukan data-data penelitian.

\section{Sumber Data}

Penelitian ini menggunakan sumber data berupa catatan-catatan dan teks-teks yang meliputi Al-Qur'an, kitab-kitab hadis, kitab-kitab fiqih, buku- buku yang berkaitan dengan hukum-hukum Islam, yang meliputi Al-Qur'an, kitab-kitab hadis, kitab-kitab fiqih, buku- buku yang berkaitan dengan hukum-hukum Islam, internet dan bukubuku yang berkaitan dengan masalah pemikiran-pemikiran Ibnu Khaldun tentang harga pasar, dan masalah intervensi pemerintah dalam penetapan harga pasar.

\section{HASIL PENELITIAN}

\section{Kebijakan Pemerintah Dalam Penentuan Harga Pasar}

Sebagaimana yang telah dijelaskan di atas bahwa penentuan harga pasar itu di tentukan oleh permintaan, penawaran dan elastisitas, adapun di negara-negara berkembang yang berkeinginan untuk mengentaskan kemiskinan serta menanggulangi ketidakmerataan distribusi 


\section{Vol. 12, No. 2, Juli 2021}

pendapatan haruslah memilih cara untuk mencapai tujuan-tujuan yang tersedia, dan memilih yang terbaik diantaranya untuk mencapai tujuan-tujuan tersebut. (Torado, 2007: 223).

\section{Pengetahuan tentang kebijakan} ekonomi berkenaan dengan usaha untuk memaksimalkan atau memenuhi solusisolusi subyek terhadap pemaksaan, namun pemaksaan-pemaksaan tersebut bukan disediakan oleh sumber-sumber dan penguasan materi saja, seperti diajarkan dalam buku- buku teks tentang perekonomian dasar, namun juga oleh etika, budaya, sejarah, dan politik.

Suatu rancangan untuk strategi pembangunan ekonomi yang berhasil dalam suatu negara Dunia Ketiga yang kontenporer, menurut pendapat dasar, namun juga oleh etika, budaya, sejarah, dan politik. Menurut pendapat beberapa pengamat, dalam hal ini harus meliputi spesifikasi tentang tiga komponen, yaitu; tujuan-tujuan, atau hasil-hasil yang diinginkan, kebijakan- kebijakan yang sesuai dengan tujuan-tujuan tersebut, dan variabelvariabel kesosialan yang akan mengarahkan pada pilihan oleh para pembuat keputusan pemerintah tentang kebijakan-kebijakan yang benar.
Dalam hal ini terkait dengan kondisi di Indonesia, pendekatan ini juga menemui jalan buntu. Bentuk pemerintah Orde Baru Presiden Soeharto, yang sudah berkuasa sejak 1966, menjadi debat seru diantara kalangan akademis, namun mereka semua setuju bahwa bentuk negaranya adalah otoriter dengan sedikit kesempatan untuk berpartisipasi. Harold Cruch, misalnya membandingkan pemerintahan Soeharto dengan kebijakan "patrimonial" Barat dimana pemerintah dapat menerapkan peraturan yang memenuhi kepentingan elit tanpa banyak mengorbankan mengorbankan kepentingan masyarakat; sementara pemerintahan Soeharto ditandai dengan kemiskinan, kemunduran sosial, sikap pasif dalam berpolitik, dan kekuasaan ditangan politikus. Politikus-pun saling bersaing hanya pada tingkat elit sendiri, diantara partai-partai yang bertujuan untuk mendapart pengaruh dari pemegang kekuasaan yang pada akhirnya menentukan distribusi berupa penghargaan. (Azizah, Mabbarok. 2012)

\section{Pandangan Ibnu Khaldun Mengenai Intervensi Pemerintah}

Ketika para labourers dan owners menolak membelanjakan tenaga, material, modal dan jasa untuk produksi kecuali 


\section{Vol. 12, No. 2, Juli 2021}

dengan harga yang lebih tinggi dari pada harga pasar wajar, pemerintah boleh menetapkan harga pada tingkat harga yang adil dan memaksa mereka untuk menjual faktor-faktor produksinya pada harga wajar. (Khaldun, 2001)

Ibnu Taimiyah menyatakan, "Jika penduduk membutuhkan jasa dari pekerja tangan yang ahli dan pengukir, dan mereka menolak tawaran mereka, atau melakukan sesuatu yang menyebabkan ketidaksempurnaan pasar, pemerintah harus mengeluarkan kebijakan penetapan harga itu untuk melindungi para pemberi kerja dan pekerja dari saling mengeksploitasi satu sama lain.? Apa yang dinyatakan itu berkaitan dengan tenaga kerja, yang dalam kasus yang sama bisa dikatakan sebagai salah satu faktor pasar (Islahi, 1997: 122).

Secara umum Ibnu Khaldun sangat menekankan pentingnya suatu sistem pasar yang bebas. Menekankan pentingnya suatu sistem pasar yang bebas. Ia menentang intervensi negara terhadap masalah ekonomi dan percaya akan efisiensi sistem pasar bebas. Ia juga telah membahas tahap - tahap pertumbuhan dan penurunan perekonomian dimana dapat saja berbeda antar satu negara dengan negara lainnya. Jika pengeluaran dan pendapatan suatu negara seimbang serta jumlahnya besar, maka akan meningkatkan pertumbuhan ekonomi. Ia juga menekankan pentingnya demand side economics khususnya pengeluaran pemerintah, sebagaimana pandangan Keneysian, untuk mencegah kemerosotan bisnis dan menjaga pertumbuhan ekonomi. Dalam situasi kemerosotan ekonomi pajak harus dikurangi dan pemerintah harus meningkatkan pengeluarannya untuk merangsang pertumbuhan ekonomi (Tim p3EI, 2012: 112-113).

\section{Pandangan Ibnu Khaldun Terhadap}

\section{Harga}

Pemikiran Ibnu Khaldun tentang pasar termuat dalam buku yang monumental, Al-Muqadimah, terutama dalam bab "Hargaharga di Kota-kota" (Prices in Towns). Ia membagi barang-barang menjadi dua kategori, yaitu barang pokokdan barang mewah. Menurutnya, jika suatu kota berkembang dan jumlah penduduknya semakin banyak, maka harga barang-barang pokok akan menurun sementara harga barang mewah akan naik (Prices in Towns). Ia membagi barang-barang menjadi dua kategori, yaitu barang-barang pokok akan menurun sementara harga barang mewah akan naik. Hal ini disebabkan oleh 
meningkatnya penawaran bahan pangan dan barang pokok lainnya sebab barang ini sangat penting dan dibutuhkan oleh orang sehingga pengadaanya akan diprioritaskan. Sementara itu barang mewah akan naik sejalan dengan meningkatnya gaya hidup yang mengakibatkan peningkatan permintaan dan penawaran terhadap tingkat harga. (Khaldun, 2001)

Secara lebih rinci ia juga menjelaskan pengaruh persaingan di antara para konsumen dan meningkatnya biayabiaya akibat perpajakan dan pungutanpungutan lain terhadap tingkat harga.

\section{Dampak Dari Intervensi Pemerintah Terhadap Penentuan Harga Pasar Menurut Ekonomi Islam}

Dampak Positif Intervensi Pemerintah Terhadap Penentuan Harga Pasar Menurut Ekonomi Konvensional Dan Islam yaitu dalam mengintervensi pasar ini telah diterima oleh tokoh ekonomi abad 20 yaitu Jhon Mydel Keynes, dia beranggapan bahwa intervensi pemerintah dalam pasar dapat menentukan dan membimbing perekonomian kearah yang diinginkan. Sedangkan Menurut Milton Friedman dari Unversity of Chicago. Bahwa dampak positif dari perekonomian yang sehat, maka pasar bebas akan dapat menjalankan fungsinya secara lebih efektif. (perkembangan pemikiran ekonomi, 2007:173).

Harus diyakini bahwa intervensi terhadap pasar hanya dapat dilakukan dalam keadaan yang darurat. Keadaan darurat disini dapat diartikan jika pasar tidak terjadi dalam keadaan sempurna, yaitu terdapat kondisi-kondisi yang menghalangi kompetisi secara fair(market failure).

Dampak Negatif Intervensi Pemerintah Terhadap Penentuan Harga Pasar Menurut Ekonomi Konvensional Dan Islam, Menurut Manan (2010: 20) bahwa ia tidak percaya mekanisme pasar saja sudah cukup untuk menentukan semua dan jumlah output, hususnya jika berhubungan dengan pemberian bagi miskin. Disebabkan oleh konsep permintaan efektif yang mendasari mekanisme pasar, ketidakmerataan pendapetan dan kekayaan pasti akan menyebabkan gagalnya mekanisme pasar dalam penyediaan kebutuhan pasar dalam penyediaan kebutuhan pasar untuk permintaan sikaya. Disinilah Manan mengemukakan konsep kebutuhan efektif

Dampak negatif dari intervensi pemerintah terhadap harga pasar adalah menurut Friedrech Von Hayek yang 


\section{Vol. 12, No. 2, Juli 2021}

tertuang dalam bukunya The Road to

Serfdom (1944) yang mengatakan sekali pemerintah melakukan intervensi pasar ini akan mengarah pada sosialisme, yang akhirnya akan menyebabkan berkurangnya kebebasan. Jika kecendrungan kearah peningkatan pengawasan pemerintah tidak dikekam, mereka hawatir bahwa orang sebagai individu-individu akan berubah sekedar menjadi hamba bagi pemerintah.

Dengan demikian, pemerintah tidak mewakili wewenang untuk melakukan intervensi terhadap harga pasar dalam kondisi normal. Ibnu Taimiyah mengatakan, jika masyarakat melakukan transaksi jual beli dalam kondisi normal tanpa ada distorsi atau penganiayaan apapun dan terjadi perubahan harga karena sedikitnya penawaran atau banyaknya permintaan, maka ini merupakan kehendak Allah..

\section{KESIMPULAN}

Dari uraian diatas yang menjadi titik pentingnya adalah bahwa regulasi Pasar dalam Islam adalah dimaksudkan agar terjaganya hak dari semua pihak, baik pembeli maupun penjual. Untuk itu perlu ditekankan disini bahwa aspek utama dalam ekonomi Islam termasuk dalam system pasar adalah aspek moralitas.

Secara singkat dan sederhana dapat ditarik kesimpulan sebagai berikut : Secara umum Ibnu Khaldun sangat menekankan pentingnya suatu sistem pasar yang yang bebas. Ia menentang intervensi negara terhadap masalah ekonomi dan percaya akan efesiensi sistem pasar yang bebas. Ia jugatelah membahas tahap-tahap pertumbuhan dan penurunan perekonomian dimana dapat saja berbeda antara suatu negara dengan negara lainnya. Jika pengeluaran dan pendapatan suatu negara seimbang serta jumlahnya besar, maka akan meningkatkan pertumbuhan ekonomi. Ia juga menekankan pentingnya demand side economics khususnya pengeluaran pemerintah. Adapun dampak positif dari intervensi pemerintah terhadap penentuan harga pasar menurut syari'at Islam adalah untuk menjaga keseimbangan harga pasar. Sedangkan dampak negatif dari intervensi pemerintah terhadap penentuan harga pasar menurut syari'at Islam adalah hilangnya kebebasan berkreasi dan mengekang kebebasan individu dan terlalu menghambat kepada pemerintah.

\section{DAFTAR PUSTAKA}

Arikunto, Suharsimi. 2013. Prosedur Penelitian: Suatu Pendekatan Praktik.

Azizah, Mabbarok. 2012. Harga yang adil dalam Mekanisme pasar dan peran pemerintah dlam perspektif islam, Jurnal Unisia, Vol 34.No. 76, Januari 2013 
Aslam Haneef, Pemikiran Ekonomi Islam Kontemporer, Rajawali Prees, Jakarta, 2010.

Dakhoir Ahmad, Ekonomi Islam Dan Mekanisme Pasar (Refleksi Pemikiran IbnuTaymiyah ), Laks Bang PRESS indo, Maret 2017.

Deliarnov, Perkembangan Pemikiran Ekonomi, Rajawali Press, Jakarta 2006.

Islahi, A. 1997, Konsep Ekonomi Ibnu Taimiyah Terjemahan H. Anshori Thoyib,. Bina Ilmu. Surabaya

Khaldun, Ibnu. 2001, Mukadimah. Jakarta: pustaka Al-Kausar, 1986. Muqaddimah, terj. Ahmadie Toha, Jakarta: Pustaka Firdaus

Manan, Abdul. 2010, "Etika Hakim Dalam Penyelenggaraan Peradilan ( Suatu. Kajian dalam Sistem Peradilan Islam ) Cetakan Ke 2", Kencana

Pemikiran Ekonomi Islam, Pt Raja Grafindo Persada, Jakarta 2010

Pusat Pengkajian Dan Pengembangan Ekonomi Islam (P3EI) Universitas Islam Indonesia Yogyakarta Atas Kerja Sama Dengan Bank Indonesia, Ekonomi Islam, Pt Raja Grafindo Persada, Jakarta, 2012.

Todaro, 1999. Faktor Yang Mempengaruhi Pertumbuhan Ekonomi Suatu Daerah. Ekonomi Perencanaan dan Pembangunan PT. Raja Grafindo Pustaka. Jakarta 